\title{
Discrimination of outcomes in a prisoner's dilemma game
}

JAMES T. TEDESCHI, DANIEL ARANOFF, AND JAMES P. GAHAGAN, DEPARTMENT OF PSYCHOLOGY, UNIVERSITY OF MIAMI, Coral Gables, Fla. 33124

An experiment was conducted to demonstrate that previous research using the PDG has neglected to separate the effects of strategy from the types of outcomes associated with two-person two-choice games, i.e., whether it be a two-outcome, threeoutcome, or standard four-outcome game. The types of outcomes and the contingent strategies of a "dummy" were manipulated. Two strategies were used in the standard PDG four-outcome game, four strategies were varied in the three-outcome game, and one strategy was used in a two-outcome game. Seventy $S s, 10$ under each strategy level, were run. A significant difference between the two-outcome game and the three- and four-outcome games on cooperation proportion over 100 iterations of the game was found. No differences were found between strategies within types. It was concluded that experimentation utilizing "dummy" strategy manipulations must not be of such a nature as to confound types of outcomes with the strategy levels. Also, a S's game behavior does not seem to be sensitive to strategy differences of the "other" player when cooperations over all trials is the dependent variable.

Since the Prisoner's Dilemma Game (PDG) is a two-person game, an independent variable which can be studied is the effect of one player's strategy selections on those of the other. Bixenstine, Potash, \& Wilson (1963) pitted an unpatterned strategy of $83 \%$ cooperations against $83 \%$ competitive responses, followed in both groups by an $83 \%$ matching strategy. McClintock et al (1963) provided unpatterned $85 \%, 50 \%$, and $15 \%$ cooperative strategies for their three groups of Ss. Neither experiment demonstrated any effect of the "other's" strategy on the choices of the Ss.

Solomon (1960), in an asymmetrical matrix game, found that more cooperative responses were made by $\mathrm{Ss}$ in a power situation when they played against a matching strategy than against either an unconditionally cooperative or unconditionally competitive strategy. Swingle \& Coady (1967) initially exposed male Ss to either a $100 \%$ or $0 \%$ cooperative partner for 50 trials in a PDG and then, in trials $51-100$, varied the dummy's strategies to either $0 \%$, $25 \%, 50 \%$, or $100 \%$ cooperations. They found that strategy changes resulted in increased variability of S's strategy.

The $S$ is always presented with a four-cell matrix even though the experiment may be so contrived that only two outcomes could occur (E matches S's choices), three outcomes could occur (an unconditional strategy by E), or four outcomes could occur. Thus, studies which manipulate strategies can be interpreted either according to the strategies employed or the number of outcomes that are possible. For example, Bixenstine \& Wilson (1963) found that $95 \%$ cooperative strategies do not induce cooperations from the S. When the dummy defects $95 \%$ of the time, the S's most frequent choice is also to defect. Either strategy approximates a three-outcome game. When E employs a 95\% cooperative strategy, it is highly improbable that the DD cell will be entered ( 25 times out of 10,000 ) and in the $95 \%$ competitive strategy game, it is highly improbable that the $\mathrm{CC}$ cell will be the outcome.

The present study was designed to control the number of outcomes for the PDG. Two strategies were varied within a four-outcome game, four strategies were varied in the threeoutcome game, and one strategy in a two-outcome PDG.

Method. Seventy Ss, 30 females and $\mathbf{4 0}$ males, from University of Miami Introductory Psychology courses were randomly assigned to play one of the three types of games. Each S played against a preplanned set of strategies manipulated by $E$ and specific to the group assignment. There were $10 \mathrm{Ss}$ in Group 1 (the two-out come game), $40 \mathrm{Ss}$ in Group 2 (the three-outcome game utilized four strategy levels), and $20 \mathrm{Ss}$ in Group 3 (the four-outcome game used two strategy levels).
In the two-outcome game, $E$ played $\mathrm{C}$ whenever the $\mathrm{S}$ played a $\mathrm{C}$ and played a $D$ in response to every $D$ choice by the $S$. E's strategy varied, however, in the three-cell games depending on the strategy involved. In the first condition, E played a $\mathrm{C} 75 \%$ of the time in response to a $\mathrm{C}$ choice by the $S$ and played a D $100 \%$ of the time in response to a S's D choice. The second condition was the reverse: $\mathrm{E}$ played a $\mathrm{C} 100 \%$ of the time in response to a $\mathrm{C}$ choice by the S and played a D only $75 \%$ of the time in response to a D choice by the $\mathrm{S}$. In the third three-outcome game condition, $\mathrm{E}$ played a $\mathrm{C}$ $50 \%$ of the time in response to a C choice by the $\mathrm{S}$ but played a D $100 \%$ of the time in response to a S'S D choice. In the last three-outcome game condition, the E played a C $100 \%$ of the time in response to a $\mathrm{C}$ choice by the $\mathrm{S}$, and played a D only $50 \%$ of the time in response to a D choice by the S. The strategies involved in the four-outcome PDG were as follows: In the first condition, $\mathrm{E}$ played a $\mathrm{C} 75 \%$ of the time in response to a $\mathrm{C}$ choice by the $\mathrm{S}$ and played a D $25 \%$ of the time when the choice of the S was a D. The second four-outcome strategy condition was for E to play a C $50 \%$ of the time when the S chose a C and to play a D $50 \%$ of the time when the $\mathrm{S}$ chose a D. All groups played 100 iterations of the game.

The apparatus and procedures are completely described in Stecle \& Tedeschi (1967). The matrix used had values of $R=85, T=100, S=35$, and $P=40$. The rules of the PDG are met by these values. ${ }^{2}$

Results. An analysis of the proportion of cooperative strategy choices over the 100 trials by type of game yielded significant differences $(F=8.26, \mathrm{df}=2 / 67, \mathrm{p}<.001)$. Sheffe's test for multiple comparisons indicated that two-outcome games yielded greater cooperative proportions than both three- $(p<.005)$ and fouroutcome games $(\mathrm{p}<.001)$. Table 1 presents the proportion of cooperative strategy choices generated by each type of game. The analysis of proportion of cooperative strategy choices across the strategy conditions indicated no differences.

Discussion. The typical procedure involved when using the PDG as a research tool is to provide the $S$ with a matrix form of the game. The $S$ is thus led to believe that four outcomes are possible. If less than four outcomes occur in the course of play, the S apparently learns to adapt his strategy selections to that fact. In chess, even if a player does not move his knight, you cannot ignore the possibility that he will. You are not always aware of your opponent's self-imposed restrictions. But, on the other hand, if your opponent consistently refrains from doing something which to you appears to be advantageous to him, then you begin to react to him as if he has some self-imposed restrictions. A clever opponent often leads you to this conclusion and into a trap.

Two-outcome games are clearly discriminated as different from threcoutcome and four-outcome games. Ss cooperate more in the two-outcome game. In the two-outcome game it was clearly to the advantage of the $S$ to cooperate since the E matched S's responses. Thus, when S cooperated, he won points but when he defected, he always lost points. A simple reward-punishment principle leads to the prediction of high cooperations. When shifting to a three- or four-outcome game, the opponent is clearly varying his responses and consequently the predictability of outcomes is much lower. In response to uncertainty the $S$ tends to minimax by choosing to defect so that his worst outcome is his minimum loss.

These results support the findings that clear shifts to $100 \%$ or slightly less

Table 1

Scheffe Test Between Types of Two-person Games on the Dependent Variable of Cooperative Strategy (CP)

\begin{tabular}{lcc}
\multicolumn{1}{c}{ Types of Outcome } & N & Mean \\
\hline Two-outcome game (Group 1) & 10 & .669 \\
Three-outcome game (Group 2) & 40 & .450 \\
Four-outcome game (Group 3) & 20 & .388 \\
\hline
\end{tabular}

Comparisons:

Group 1 vs Group 2

Group 1 vs Group 3

Group 2 vs Group 3

$\mathbf{p}<.005$

$\mathrm{p}<.001$

$\mathrm{p}<.464$ 
cooperative or competitive strategy selections do change the response patterns of Ss but that wide ranges of variations in strategy selections which yield three or four outcomes do not produce variations in S's strategy selections. The lack of predictability of the other's responses leads to uncertain outcomes and uncertain outcomes are responded to with a predominantly minimax strategy.

\section{REFERENCES}

BIXENSTINE, V. E., POTASH, H. M., \& WILSON, K. V. Effects of level of cooperative choice by the other player on choices in a prisoner's dilemma game: Part I. J. abnorm soc. Psychol., 1963, 66, 308-313.

BIXENSTINE, V. E., \& WILSON, K. V. Effects of level of cooperative choices in a Prisoner's Dilemma Game: Part II. J. abnorm soc. Psychol, $1963,67,139-147$.

McClINTOCK, C. G., HARRISON, A., STRAND, S., \& GALLO, P. Internationalism, isolationism, strategy of the other player, and two-person game behavior. J. abnorm soc. Psychol, 1963, 67, 631-635.

RAPOPORT, A., \& CHAMMAH, A. M. Prisoner's dilemma. Ann Arbor:
University of Michigan Press, 1965.

SOLOMON, L. The influence of some types of power relationships and game strategies upon the development of interpersonal trust. J. abnorm. soc. Psychol, 1960, 61, 223-230.

STEELE, M. W., \& TEDESCHI, J. T. Matrix indices and mixed-motive games. $J$. conflict Resolut., 1967, 11, 198-205.

SWINGLE, P. G., \& COADY, H. Effects of the partner's abrupt strategy change upon subject's responding in the prisoner's dilemma. J. Pers. soc. Psychol., 1967, 5(3), 357-364.

\section{NOTES}

1. Based on a paper read as a part of a symposium on "The Prisoner's Dilemma Game" at the annual meeting of the Southeastern Psychological Association in Atlanta, April, 1967.

2. The notation used referring to matrix values and the rules of the PDG can be found in Rapoport \& Chammah (1965). 